\title{
Organ-specific accumulation of toxic elements in Hilsa shad (Tenualosa ilisha) from Bangladesh and human health risk assessment
}

\author{
Mohammad Raknuzzaman ${ }^{1}$, Md. Habibullah-Al-Mamun ${ }^{1}$, Anwar Hossain ${ }^{1}$, Masahiro Tokumura², Shigeki \\ Masunaga $^{3}$ \\ 'Department of Fisheries, University of Dhaka, Dhaka 1000, Bangladesh. \\ ${ }^{2}$ Graduate School of Nutritional and Environmental Science, University of Shizuoka, Shizuoka 422-8526, Japan. \\ ${ }^{3}$ Graduate School and Faculty of Environment and Information Sciences, Yokohama National University, Yokohama, Kanagawa \\ 240-8501, Japan.
}

Correspondence to: Dr. Md. Habibullah-Al-Mamun, Department of Fisheries, Faculty of Biological Sciences, University of Dhaka, Dhaka 1000. E-mail: almamunhabib@du.ac.bd

How to cite this article: Raknuzzaman M, Habibullah-Al-Mamun M, Hossain A, Tokumura M, Masunaga S. Organ-specific accumulation of toxic elements in Hilsa shad (Tenualosa ilisha) from Bangladesh and human health risk assessment. J Environ Expo Assess 2022;1:4. https://dx.doi.org/10.20517/jeea.2021.05

Received: 1 Oct 2021 First Decision: 9 Nov 2021 Revised: 20 Dec 2021 Accepted: 28 Dec 2021 Published: 7 Jan 2022

Academic Editor: Stuart Harrad Copy Editor: Yue-Yue Zhang Production Editor: Yue-Yue Zhang

\begin{abstract}
Purpose: We aimed to determine the amount of some toxic elements in three organs of Hilsa shad, focusing on the possible exposure to human health through Hilsa consumption. This study was designed to determine the concentration of seven toxic trace elements ( $\mathrm{As}, \mathrm{Cd}, \mathrm{Cr}, \mathrm{Cu}, \mathrm{Ni}, \mathrm{Pb}$, and $\mathrm{Zn})$ in three distinct organs $(n=21)$ (muscle, liver, and gills) of Hilsa shad (Tenualosa ilisha) fish collected from the Bangladeshi coastal area. The samples were digested following a microwave digestion. Inductively coupled plasma mass spectrometer was used as analytical instrument. Estimated daily intakes (EDI) and target cancer risk (TR) were used to evaluate carcinogenic and non-carcinogenic risk.
\end{abstract}

Results: The mean concentrations ( $\mathrm{mg} / \mathrm{kg}$-wet weight) of toxic elements in different organs of $T$. ilisha were determined as follows: in muscle, As (4.05), $\mathrm{Cd}(0.09), \mathrm{Cr}(0.12), \mathrm{Cu}(0.77), \mathrm{Ni}(0.26), \mathrm{Pb}(0.20)$, and $\mathrm{Zn}(10.64)$; in liver, $\mathrm{As}$ (2.83), $\mathrm{Cd}(0.84), \mathrm{Cr}(0.18), \mathrm{Cu}$ (6.17), $\mathrm{Ni}(0.55), \mathrm{Pb}(0.23)$, and $\mathrm{Zn}$ (30.16) and in gills, As (3.45), Cd (0.05), $\mathrm{Cr}$ (0.08), $\mathrm{Cu}(1.06), \mathrm{Ni}(0.51), \mathrm{Pb}(0.78)$, and $\mathrm{Zn}$ (35.21). The liver showed higher concentrations of most elements than that of muscle except for As. Concentration of $\mathrm{As}, \mathrm{Cd}$, and $\mathrm{Pb}$ in the fish were found above the food safety guidelines, while other trace element concentrations were below the permissible range for human

The Author(s) 2022. Open Access This article is licensed under a Creative Commons Attribution 4.0 International License (https://creativecommons.org/licenses/by/4.0/), which permits unrestricted use, sharing, adaptation, distribution and reproduction in any medium or format, for any purpose, even commercially, as long as you give appropriate credit to the original author(s) and the source, provide a link to the Creative Commons license, and indicate if changes were made. 
consumption. According to EDI and TR values, there were carcinogenic and non-carcinogenic risks from exposure to total As concentration from Hilsa fish consumption.

Conclusion: This study suggests that the toxic trace elements contamination levels in Hilsa fish from Bangladesh's coastal area need to be monitored on a systematic and regular basis to ensure the safety of this food item for human consumption.

Keywords: Trace elements, arsenic, hilsa shad, health risk, Bangladesh

\section{INTRODUCTION}

Trace elements are the most hazardous to aquatic ecosystems because they are widespread in the environment, widely dissolved in water, and rapidly absorbed by aquatic organism ${ }^{[1-3]}$. Metals enter the environment naturally through air deposition, geological matrix attrition, and anthropogenic intrusions including sewage, industrial, and agricultural runoff ${ }^{[4]}$. Because of their toxicity, persistence, and bioaccumulation in food chains, trace elements in aquatic environments may have an impact on fish and other biological life $e^{[5,6]}$. The aquatic environment is one of the most regularly monitored areas where different organisms will be vulnerable depending on the type of contaminant, habitat, position in the food chain that the organism occupies, etc. ${ }^{[7]}$. Fish have been recommended as valuable biological indicators for the assessment of aquatic pollution because they are large in size, considered as resident species, adult, perennial, and easily identified in aquatic medium ${ }^{[8]}$. In addition, they have a longer life span and a higher position in the aquatic food chain $^{[9]}$, and thus have been suggested as useful biological markers in the assessment of aquatic environmental pollution ${ }^{[10,11]}$.

The concentrations of trace elements accumulated in a fish's body greatly vary among its different organ ${ }^{[12-15]}$. Fish absorb trace elements by ingesting of particulate matter from water, taking of foods, grazing food from sediments through the gills, and adsorption on tissues. The distribution of metals in different tissues of fish depends on the mode of exposure, biokinetics of the elements, lipophilic properties, etc. ${ }^{[16-18]}$. Furthermore, the accumulation rates of trace elements in fish are affected by both absorption and removal processes ${ }^{[19-21]}$.

However, very few studies in Bangladesh have concentrated on the increasing high levels of trace elements in different organs of the fish (e.g., muscle, gills, and liver). Gills and liver are considered as indicators for measuring metal accumulation in fish. Metal accumulation is also measured using the gills and liver as markers. Metal concentrations in gills represent the metal concentrations in a fish's living environment, while the liver mainly acts as metabolic organ where metals are also stored ${ }^{[22]}$ and muscle is not an active tissue in accumulating trace elements but does act as storage organ ${ }^{[23-25]}$.

The presence of metals in fish tissues is of major concern for food safety as well as public health ${ }^{[26-28]}$. As a result, metal contamination in fish has become a major problem around the world, and many studies on metal accumulation in fish have already been conducted $^{[28-32]}$.

In Bangladesh, trace element pollution in fish has become a serious public health concern. Fish are the major source of protein for Bangladeshi people, and about five million coastal residentsd are directly or indirectly engaged in commercial fishing, particularly of Hilsa shad (Tenualosa ilisha) fishing. Hilsa shad is usually known as Indian shad, which is a highly migratory fish with a similar breeding behavior to Atlantic salmon. It migrates into the Padma and Meghna Rivers and their tributaries from the Bay of Bengal for breeding and nursing. Hilsa is the most dominant, commercially important, and widely consumed fish by 
the Bangladeshi people. As a single species, it contributes 12\% of the total marine catch. Approximately, $2 \%$ of the country's population is directly or indirectly involved with Hilsa fishing ${ }^{[33]}$. Bangladesh contributes $75 \%$ of the global Hilda shad catch, and the rest comes from Myanmar (15\%), India (5\%), and 5\% from Thailand and $\operatorname{Iran}^{[33]}$.

The rapid unplanned industrialization, urbanization, and trans-boundary movement of water may contribute a considerable amount of industrial effluent and untreated domestic wastewater into the coastal water environment through rivers. As a result, trace elements contaminate coastal water, and contaminants can be deposited in aquatic organisms, including Hilsa fish, via bioconcentration, bioaccumulation, and food chain effects. Trace element contamination in Hilsa fish and other aquatic biota threatens human health via the food chain.

To the best of our knowledge, this was the first study carried out on the organ-specific trace element distribution in Hilsa shad in Bangladesh. The objective of this study was to determine the level of trace element contamination ( $\mathrm{As}, \mathrm{Cd}, \mathrm{Cr}, \mathrm{Cu}, \mathrm{Ni}, \mathrm{Pb}$, and $\mathrm{Zn}$ ) and its distribution in three organs (muscle, liver, and gills) of Hilsa shad, with a focus on the possible exposure to human health through the consumption of Hilsa shad.

\section{EXPERIMENTAL}

\section{Collection of hilsa shad}

The most consumed and commercially important fish, Hilsa shad (Tenualosa ilisha) (weight, $851.71 \pm$ $10.57 \mathrm{~g}$; length, $32.46 \pm 3.27 \mathrm{~cm}$ ) was collected from the central fish landing center, which is very close to the Bakkhali estuary of Cox's Bazar [Figure 1]. Cox's Bazar is a seaside tourist town with the world's longest sandy sea beach. Hundreds of factories and industries, such as ship breaking and building industries, paint and salt industries, fish and shrimp processing plants, textile manufacturing, fish and shrimp hatcheries, fish auction and landing center, unplanned urbanization, and several hotels, have an impact on the city. Every year, many local and international tourists visit the city. The sampling was conducted in winter (temperature range: $10-16^{\circ} \mathrm{C}$ ) from January to February 2016. The fish samples were transported to the Department of Fisheries, University of Dhaka, Bangladesh. They were washed with deionized water after transportation to remove surface adherence. With the use of a clean SS knife, the samples were chopped into small pieces according to target organs, namely gills, liver, and muscles, and separately freeze-dried $(48 \mathrm{~h})$ until a constant weight was achieved. Further chemical analysis of all processed samples was performed at the laboratory of the Yokohama National University, Japan.

\section{Sample preparation}

The samples were digested following a microwave digestion ${ }^{[34]}$. In a closed digestion vessel, $0.2 \mathrm{~g}$ of each organ of Hilsa shad was treated with $5 \mathrm{~mL}$ of $69 \% \mathrm{HNO}_{3}$ acid and $2 \mathrm{~mL}$ of $30 \% \mathrm{H}_{2} \mathrm{O}_{2}$ and mixed for 20 min. The samples were then placed in the Berghof-MWS2 (Berghof speedwave ${ }^{\bullet}$, Germany) digestion system. Acid solutions containing samples were put into a Teflon graduated cylinder after digestion, and the total volume was adjusted to $50 \mathrm{~mL}$ using Milli-Q water. The digested acid solutions were then filtered through a syringe filter (DISMIC ${ }^{\oplus} ; 0.45 \mathrm{~m}$ ) and stored in $50 \mathrm{~mL}$ PP tubes.

\section{Instrumental analysis}

The samples were analyzed using inductively coupled plasma mass spectrometer (ICP-MS, Agilent 7700 series, USA) following the previous method ${ }^{[34]}$. Briefly, the calibration curve was prepared using a multielement standard (SPEX CertiPrep ${ }^{\star}$, USA) solution. For concentration calculations, calibration curves with $R^{2}>0.999$ were accepted. The relative standard deviation $(\mathrm{RSD}<5 \%)$ was checked using a tuning solution before starting the analysis ( $1 \mu \mathrm{g} / \mathrm{L}$ each of $\mathrm{Li}, \mathrm{Y}, \mathrm{Ce}, \mathrm{Tl}, \mathrm{Mg}$, and $\mathrm{Co}$ in $2 \% \mathrm{HNO}_{3}$ ). Dilution of the multi- 


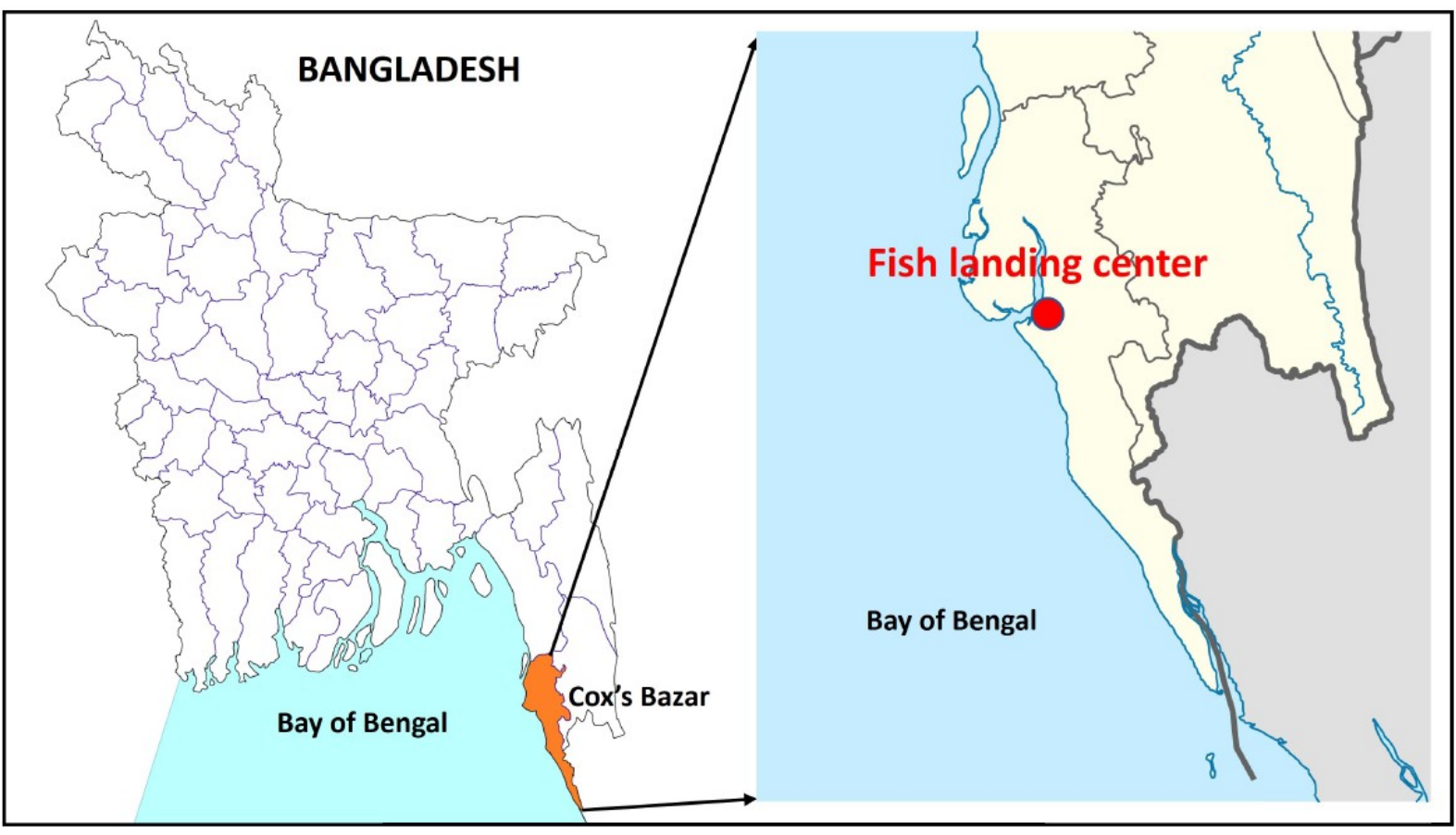

Figure 1. Map showing sampling site (main fish landing center at Cox's Bazar, Bangladesh).

element stock solution yielded working standards (0, 10, 20, 50, and $100 \mathrm{~g} / \mathrm{L})$. An internal standard method was used to determine trace element concentrations. In the current investigation, the trace element concentrations in Hilsa shad ( $T$. ilisha) were assessed on a wet weight (ww) basis.

\section{Quality control and quality assurance}

To maintain strict quality control and assurance, Internal Quality Controls were maintained for all test batches and validated. The experiment included a blank, a certified reference material (CRM), and some samples that were examined in triplicate to remove the batch-specific error. NMIJ CRM 7402-a, cod fish tissue, as a certified reference material, was used to check the quality. The CRM recoveries ranged from $91 \%$ to $106 \%$, with the triplicate reproducibility ranging from $93 \%$ to $97 \%$, confirming the acceptable accuracy and precision of the method.

\section{Health risk assessment}

Estimated daily intakes (EDI) and target cancer risk (TR) were used to quantify the risk of trace element concentrations in the fish. Because the human population in the vicinity consumes fish tissues such as gills, muscles, and liver, all of these tissues were considered in the risk evaluation.

$E D I$

EDI ( $\mu \mathrm{g} / \mathrm{kg}$-bw/day) were calculated for the detected trace elements by using Equation (1):

$$
E D I=\frac{F I R \times C}{W A B}
$$

where FIR is the food ingestion rate $\left(77 \mathrm{~g} /\right.$ day for adults) ${ }^{[34]}, \mathrm{C}$ is the metal concentration in samples $(\mu \mathrm{g} / \mathrm{g}-\mathrm{ww})$, and WAB is the average body weight (60 kg for adults). 


\section{Carcinogenic health risk assessment}

TR over a lifetime was used to assess the carcinogenic health concerns associated with fish consumption in this study. TR was calculated using Equation $(2)^{[35]}$ :

$$
T R=\frac{E F \times E D \times F I R \times C \times C S F_{0}}{W A B \times T A} \times 0.001
$$

where $\mathrm{EF}$ is the exposure frequency (365 days per year), ED is the exposure duration (60 years for Bangladesh), FIR is the fish ingestion rate, $\mathrm{C}$ is the metal concentration in fish, WAB is the average body weight, TA is the exposure time (365 days per year $\times \mathrm{ED}$ ), and CSFo is the oral carcinogenic slope factor for As and $\mathrm{Pb}$, cosidered as $1.5(\mathrm{mg} / \mathrm{kg}-\mathrm{d})^{-1}$ and $0.0085\left(\mathrm{mg} / \mathrm{kg}^{-\mathrm{d})^{-1}}\right.$, respectively ${ }^{[36]}$.

\section{Statistical analysis}

Concentrations of trace elements, expressed as $\mathrm{mg} / \mathrm{kg}-\mathrm{ww}$, are presented in the form of mean, standard deviation and range (minimum-maximum). Overall mean concentrations of trace elements were calculated as the average of the three organs. The dataset was normally distributed (evaluated by P-P plot). Variations of trace element concentrations among the three fish organs (muscle, liver, and gill) were tested by a oneway ANOVA analysis followed by Tukey's HSD post hoc test. Statistical analyses were carried out using SPSS (Version 25.0, IBM Corp., NY, USA) and the level of significance was $P<0.05$.

\section{RESULTS AND DISCUSSION}

\section{Trace elements concentration in muscle, liver and gills of Hilsa shad}

The concentrations of seven trace elements detected in muscle, liver, and gills of Hilsa shad are presented in Table 1. The trace element concentrations in three organs of the Hilsa shad were detected in a wide range. The trace element concentrations were found in three organs of Hilsa shad in the following ranges: $\mathrm{Cr}$ (0.06-0.17 mg/kg), Ni (0.08-0.72 mg/kg), Cu (0.52-1.1 mg/kg), Zn (7.99-17.49 mg/kg), As (2.25-5.59 mg/kg), $\mathrm{Cd}(0.05-0.17 \mathrm{mg} / \mathrm{kg})$, and $\mathrm{Pb}(0.10-0.31 \mathrm{mg} / \mathrm{kg})$ in muscle; $\mathrm{Cr}(0.08-0.32 \mathrm{mg} / \mathrm{kg}), \mathrm{Ni}(0.17-2.01 \mathrm{mg} / \mathrm{kg}), \mathrm{Cu}$ (2.15-17.16 mg/kg), Zn (23.12-43.40 mg/kg), As (1.72-4.44 mg/kg), Cd (0.35-1.43 mg/kg), and Pb (0.16$0.34 \mathrm{mg} / \mathrm{kg}$ ) in liver; and $\mathrm{Cr}(0.05-0.10 \mathrm{mg} / \mathrm{kg}), \mathrm{Ni}(0.19-1.71 \mathrm{mg} / \mathrm{kg}), \mathrm{Cu}(0.84-1.30 \mathrm{mg} / \mathrm{kg}), \mathrm{Zn}(27.66-$ $47.90 \mathrm{mg} / \mathrm{kg}), \mathrm{As}(2.32-4.07 \mathrm{mg} / \mathrm{kg}), \mathrm{Cd}(0.02-0.08 \mathrm{mg} / \mathrm{kg})$, and $\mathrm{Pb}(0.58-1.03 \mathrm{mg} / \mathrm{kg})$ in gills. The mean concentration of the metals examined in Hilsa decreased in the order of: $\mathrm{Zn}>\mathrm{As}>\mathrm{Cu}>\mathrm{Ni}>\mathrm{Pb}>\mathrm{Cr}>\mathrm{Cd}$ in muscle; $\mathrm{Zn}>\mathrm{Cu}>\mathrm{As}>\mathrm{Cd}>\mathrm{Ni}>\mathrm{Pb}>\mathrm{Cr}$ in liver; and $\mathrm{Zn}>\mathrm{As}>\mathrm{Cu}>\mathrm{Ni}>\mathrm{Pb}>\mathrm{Cd}>\mathrm{Cr}$ in gills. When total metal concentration was taken into account, the investigated metals in Hilsa followed a decreasing order of: $\mathrm{Zn}>\mathrm{As}>\mathrm{Cu}>\mathrm{Ni}>\mathrm{Pb}>\mathrm{Cd}>\mathrm{Cr}$. The highest mean concentration of most metals, except As and $\mathrm{Zn}$, was found in the liver, while muscle showed the lowest concentration except for As [Table 1]. Our results corroborate the previous findings ${ }^{[11,42]}$. The toxic elements accumulated in the liver at high concentrations, resulting from the liver's higher accumulating ability ${ }^{[41,43,44]}$. Many scientists believe that fish liver is the most accurate environmental indicator for measuring both water pollution and chronic trace element intake ${ }^{[45,46]}$. Fish muscle tissue, on the other hand, is not as active in binding metals. As a result, compared to other tissues and organs, the accumulation of metals in muscle is minimal ${ }^{[3,47]}$.

Among the three organs, gills had the highest mean content of $\mathrm{Zn}(35.21 \mathrm{mg} / \mathrm{kg})$ and the lowest concentration of $\mathrm{Cd}(0.05 \mathrm{mg} / \mathrm{kg})$. Moreover, a significant concentration of As $(3.5 \mathrm{mg} / \mathrm{kg})$ was also observed in gills, which was higher than that of the liver $(2.8 \mathrm{mg} / \mathrm{kg}$ ) [Table 1]. Metal contamination in the surrounding water environment is often reflected in the gills of fish ${ }^{[48]}$. Gills come into close contact with suspended particulates in water, and, as a result, different metals from the aqueous environment may be absorbed. The elevated metal concentrations in gills could be linked to trace element pollution in the living 
Table 1. The concentrations ( $\mathrm{mg} / \mathrm{kg} ; \mathrm{ww}$ ) of trace elements in the three organs (muscle, liver, and gills) of Hilsa shad $(n=21)$ and different national and international FSG values

\begin{tabular}{|c|c|c|c|c|c|c|c|c|}
\hline \multirow{2}{*}{ Fish organs } & & \multicolumn{7}{|c|}{ Concentrations of trace elements (mg/kg; ww) } \\
\hline & & As & Cd & $\mathrm{Cr}$ & $\mathrm{Cu}$ & $\mathbf{N i}$ & $\mathbf{P b}$ & Zn \\
\hline \multirow[t]{3}{*}{ Muscle } & Mean & $4.05^{a}$ & $0.09^{\mathrm{a}}$ & $0.12^{a, b}$ & $0.77^{\mathrm{a}}$ & $0.26^{\mathrm{a}}$ & $0.2^{\mathrm{a}}$ & $10.64^{\mathrm{a}}$ \\
\hline & SD & 1.18 & 0.04 & 0.03 & 0.21 & 0.22 & 0.08 & 3.2 \\
\hline & Range & $2.25-5.59$ & $0.05-0.17$ & $0.06-0.17$ & $0.52-1.1$ & $0.08-0.72$ & $0.10-0.31$ & 7.99-17.49 \\
\hline \multirow[t]{3}{*}{ Liver } & Mean & $2.83^{\mathrm{b}}$ & $0.84^{\mathrm{b}}$ & $0.18^{\mathrm{a}}$ & $6.17^{\mathrm{b}}$ & $0.55^{\mathrm{a}}$ & $0.23^{\mathrm{a}}$ & $30.16^{\mathrm{b}}$ \\
\hline & SD & 0.97 & 0.44 & 0.09 & 5.11 & 0.65 & 0.06 & 6.75 \\
\hline & Range & $1.72-4.44$ & $0.35-1.43$ & $0.08-0.32$ & $2.15-17.16$ & $0.17-2.01$ & $0.16-0.34$ & $23.12-43.40$ \\
\hline \multirow[t]{3}{*}{ Gills } & Mean & $3.45^{\mathrm{a}}$ & $0.05^{a}$ & $0.08^{b}$ & $1.06^{\mathrm{a}}$ & $0.51^{\mathrm{a}}$ & $0.78^{b}$ & $35.21^{b}$ \\
\hline & SD & 0.6 & 0.02 & 0.02 & 0.15 & 0.53 & 0.21 & 7.27 \\
\hline & Range & $2.32-4.07$ & $0.02-0.08$ & $0.05-0.10$ & $0.84-1.30$ & $0.19-1.71$ & $0.58-1.03$ & $27.66-47.90$ \\
\hline Overall mean & & 3.4 & 0.3 & 0.1 & 2.7 & 0.4 & 0.4 & 25.3 \\
\hline FSG & & $2^{[37]}$ & $0.05^{[38]}$ & $1^{[39]}$ & $20^{[38]}$ & $0.5^{[40]}$ & $0.3^{[38]}$ & $50^{[38]}$ \\
\hline
\end{tabular}

Horizontally, ${ }^{a, b}$ denote significant difference at $P<0.05$ among the different organs of Hilsa shad for each metal. SD: Standard deviation; wW: wet weight; FSG: food safety guideline.

environment of fish. Furthermore, metal absorption onto the gill surface can affect the overall metal levels in gills ${ }^{[2,45]}$. In addition, relatively higher concentrations of metals in the liver and gills of fish have also been reported previously ${ }^{[49,50]}$.

The maximum concentration $(5.59 \mathrm{mg} / \mathrm{kg}-\mathrm{ww})$ of As was detected in muscle, while the lowest concentration $(1.72 \mathrm{mg} / \mathrm{kg}-\mathrm{ww})$ was found in the liver [Table 1]. The mean concentration of As in muscle, liver, and gills exceeded the food safety guideline values [Table 1]. Delgado-Andrade et al..$^{[51]}$ (2003) reported the total As in fish muscle ranged from 0.39 to $12.58 \mathrm{mg} / \mathrm{kg}$ from southeast Spain. Arsenic concentrations in Bangladeshi freshwater fish species have been recorded in the range of $1.01-15.2 \mathrm{mg} / \mathrm{kg}$ - $\mathrm{dw}$ in earlier studies $^{[52]}$. The maximum arsenic concentration level permitted for fish muscle is $2.0 \mathrm{mg} / \mathrm{kg}$-ww according to the New Zealand food safety standard ${ }^{[37]}$. Chronic exposure to arsenic can cause dermatitis, mild skin pigmentation keratosis, reduced nerve movement velocity, and lung cancer. Arsenic can be found in two forms in fish, inorganic and organic. Organic As, while present in large concentrations in fish, is far less hazardous than inorganic arsenic and can be eliminated in urine efficiently and quickly without transformation ${ }^{[53]}$. Inorganic As, on the other hand, is thought to be carcinogenic in fish consumed by humans $s^{[54]}$.

Cadmium is an extremely hazardous element that occurs naturally in soil but is also distributed throughout the environment as a result of human activity. Even at low quantities, it could be one of the most poisonous trace elements ${ }^{[5]}$ and could be particularly harmful to fish genetic material ${ }^{[7]}$. Cadmium accumulates in various organs and has a significant potential for bioconcentration in fish. The highest Cd content was found in the liver $1.43 \mathrm{mg} / \mathrm{kg}$ - ww and the lowest concentration was found in gills $0.02 \mathrm{mg} / \mathrm{kg}$-ww. Other fish species had a similar Cd distribution pattern (highest levels in the liver, lowest in muscle) ${ }^{[45,56]}$. Cadmium levels in fish muscle were found to be in the range of $0.51-0.73 \mathrm{mg} / \mathrm{kg}$ - dw in samples from the Dhaleshwari River in Bangladesh ${ }^{[57]}$. A maximum Cd level of $0.05 \mathrm{mg} / \mathrm{kg}$ in fish muscle is set by European Community regulation ${ }^{[38]}$.

The liver had the greatest concentration of $\mathrm{Cr}(0.32 \mathrm{mg} / \mathrm{kg}$-ww), while gills had the lowest concentration $(0.05 \mathrm{mg} / \mathrm{kg}-\mathrm{ww})$. Cr levels in edible fish muscles from Bangladesh ranged from 0.47 to $2.07 \mathrm{mg} / \mathrm{kg}$ - $\mathrm{dw}^{[58]}$, and $\mathrm{Cr}(4.64 \mathrm{mg} / \mathrm{kg})$ was found in Mystus bleekeri of Dhaleshwari River ${ }^{[32]}$. Matasin et al. ${ }^{[59]}$ (2011) reported 
similar Cr concentrations in edible Silurius glanis tissue $(0.23 \mathrm{mg} / \mathrm{kg})$.

Copper is necessary for good health, but excessive amounts can cause issues such as liver and kidney damage ${ }^{[60]}$. $\mathrm{Cu}$ concentrations in the liver were the highest $(17.16 \mathrm{mg} / \mathrm{kg}-\mathrm{ww})$, while the lowest $(0.52 \mathrm{mg} / \mathrm{kg}-\mathrm{ww})$ were found in muscle [Table 1]. Copper concentrations in fish muscle from the Dhaleshwari River, Bangladesh, have previously been found to be in the range of 5.17-9.45 mg/ $\mathrm{kg}^{[57]}$. Copper levels in fish muscle from the Northeast Atlantic have been recorded in the range of 0.11-0.97 mg/kg and 0.04-5.43 mg/kg-ww in the Iskenderun Bay, Turkey ${ }^{[6,62]}$. The concentration of $\mathrm{Cu}$ in this investigation was below acceptable levels when compared to international guidelines [Table 1].

Nickel is found in the environment at extremely low quantities; however, it can cause a number of respiratory health problems, including lung inflammation, fibrosis, emphysema, and malignancies ${ }^{[63]}$. Among the metals, the highest Ni concentration was recorded in the liver $(2.01 \mathrm{mg} / \mathrm{kg}-\mathrm{ww})$, which exceeded the WHO recommended food safety guideline $(0.5 \mathrm{mg} / \mathrm{kg}$-ww), while the lowest concentration was observed in muscle $(0.08 \mathrm{mg} / \mathrm{kg}-\mathrm{ww})^{[40]}$ [Table 1]. The highest concentration of $\mathrm{Ni}$ in the liver of the present study differed from previous findings ${ }^{[64,65]}$. Nickel concentrations in fish have been recorded in the range of $0.11-12.88 \mathrm{mg} / \mathrm{kg}-\mathrm{dw}$ for Iskenderun Bay fish species $^{[62]}$.

Lead is a non-essential and toxic element which may induce neurotoxicity, toxicity in the kidney, and a variety of other health problems ${ }^{[66]}$. Gills had the highest $\mathrm{Pb}$ content $(1.03 \mathrm{mg} / \mathrm{kg}$-ww), exceeding the European Community limit of $0.3 \mathrm{mg} / \mathrm{kg}$, while muscle had the lowest $(0.2 \mathrm{mg} / \mathrm{kg}-\mathrm{ww})$. Pb levels in fish species have been previously reported as $0.09-6.95 \mathrm{mg} / \mathrm{kg}-\mathrm{dw}$ in Iskenderun Bay, Turkey ${ }^{[2]}$. Our findings are consistent with the findings of Storelli et al. ${ }^{[6]}$ (2006), who found that gills had the greatest amounts of $\mathrm{Pb}$. Furthermore, the previous study found that $\mathrm{Pb}$ concentration in the range of $1.76-10.27 \mathrm{mg} / \mathrm{kg}$ in various edible Bangladeshi fish ${ }^{[58]}$. Gills were found to contain levels of lead above detection thresholds, which is consistent with earlier results that gills were the primary site of metal accumulation ${ }^{[2,65]}$. Gills serve as a direct metal absorption site from water ${ }^{[64]}$.

The highest mean concentration of $\mathrm{Zn}(35.21 \mathrm{mg} / \mathrm{kg}-\mathrm{ww})$ was detected in gills, while the lowest concentration (10.64 mg/kg-ww) was observed in muscle [Table 1]. The greatest $\mathrm{Zn}$ concentrations in fish gills have been reported in several earlier investigations ${ }^{[45,56]}$. Gills help with a variety of physiological functions, including as osmoregulation and gas exchange. The exchange of trace elements between fish and their aquatic environment influences fish gills ${ }^{[67]}$. Furthermore, the elevated $\mathrm{Zn}$ content might be linked to the outflow of various fish processing plants as well as from fish and shrimp hatcheries where zinc oxide $(\mathrm{ZnO})$ is typically used to provide oxygen to fish and shrimp larvae. Certain edible fish in Bangladesh had $\mathrm{Zn}$ levels ranging from 42.8 to $418 \mathrm{mg} / \mathrm{kg}^{[58]}$, and the concentration of $\mathrm{Zn}$ in different fish of the Black Sea in Turkey ranged from 38.8 to $93.4 \mathrm{mg} / \mathrm{kg}^{[68]}$.

\section{Health risk assessment}

The EDI and the oral reference dose (RfD) of detected trace elements from Hilsa consumption among Bangladeshi coastal adults are shown in Table 2. Human exposure to trace elements can take various forms, including inhalation and skin contact. Food consumption is frequently considered as one of the most significant exposure routes. With the exception of As, the average EDI of other metals in fish were below their respective RfD, indicating that regular Hilsa fish intake would not pose a health concern. However, dietary As intakes (4.4 $\mu \mathrm{g} / \mathrm{kg}$-bw/day) from Hilsa fish consumption surpassed the $\mathrm{RfD}(0.3 \mu \mathrm{g} / \mathrm{kg}$-bw/day), potentially resulting in As-induced adverse consequences in human health. 
Table 2. TR of trace elements due to the consumption of Hilsa fish collected from the Bangladeshi coast

\begin{tabular}{lllll}
\hline Metals & $\begin{array}{l}\text { Overall mean concentration } \\
(\mu \mathrm{g} / \mathrm{g} \text {-ww) }\end{array}$ & $\begin{array}{l}\text { Estimated daily intake (EDI) } \\
(\boldsymbol{\mu g} / \mathbf{k g}-\text { bw/day) }\end{array}$ & $\begin{array}{l}\text { RfD } \\
(\boldsymbol{\mu g} / \mathbf{k g} \text {-bw/day) }\end{array}$ & TR \\
\hline $\mathrm{As}$ & 3.4 & 4.4 & 0.3 & $6.63 \times 10^{-4}$ \\
$\mathrm{Cd}$ & 0.3 & 0.4 & 1 & \\
$\mathrm{Cr}$ & 0.1 & 0.2 & 3 & \\
$\mathrm{Cu}$ & 2.7 & 3.4 & 40 & $4.42 \times 10^{-6}$ \\
$\mathrm{Ni}$ & 0.4 & 0.6 & 20 & 3.5 \\
$\mathrm{~Pb}$ & 0.4 & 0.5 & 300 & \\
$\mathrm{Zn}$ & 25.3 & 32.5 & & \\
\hline
\end{tabular}

TR: Target cancer risk; RfD: reference dose.

Table 2 shows the TR of As and $\mathrm{Pb}$ resulting from Hilsa fish intake. The TR values for As (assuming 10\% inorganic As in marine fish ${ }^{[51]}$ and $\mathrm{Pb}$ from sea food consumption were $6.63 \times 10^{-4}$ and $4.42 \times 10^{-6}$, respectively. In general, cancer risks of less than $10^{-6}$ are regarded as negligible, cancer risks of more than $10^{-4}$ are unacceptable, and risks of $10^{-6}$ to $10^{-4}$ are within the acceptable range ${ }^{[35,36]}$. Pb showed a carcinogenic risk that was near the permissible limit, whereas As had a risk that was in the unacceptable range. As a result, the possible health risk posed by metal exposure from Hilsa fish intake should not be overlooked.

\section{CONCLUSION}

The purpose of this study was to investigate the distribution pattern of some trace elements in various organs of commercially significant Hilsa fish and to assess the potential health risk associated with the consumption of this fish. The results of this investigation indicated a significant degree of differential accumulation of the investigated trace elements in three distinct tissues of Hilsa shad. The higher concentration of detected trace elements was found in the liver, while muscle exhibited the lowest amounts of analyzed metals. Except for $\mathrm{Zn}$ and As, which surpassed international quality requirements, trace element quantities in the tissue were below permissible limits for human consumption. The EDI and TR values indicated a high likelihood of carcinogenic and non-carcinogenic health consequences from consuming Hilsa fish. To reduce the negative consequences induced from As bioaccumulation, excessive consumption of Hilsa fish should be avoided. Where urgent control and more thorough investigations are needed, this circumstance should not be overlooked. Our findings suggest that further research is urgently needed to draw a conclusion about the trace element contamination in Hilsa shad of Bangladesh.

\section{DECLARATIONS}

\section{Acknowledgments}

The authors gratefully acknowledge the lab members of the Department of Fisheries, University of Dhaka, Bangladesh and Masunaga lab, Yokohama National University, Japan for their tremendous support during sample collection, processing and instrumental analysis.

\section{Authors' contributions}

Made substantial contributions to conception and design of the study and performed data analysis and interpretation: Raknuzzaman M, Habibullah-Al-Mamun M, Hossain A

Performed data acquisition, as well as provided administrative, technical, and material support: Tokumura M, Masunaga S 


\section{Availability of data and materials}

Not applicable.

\section{Financial support and sponsorship}

The authors would like to express their gratitude to Graduate School of Environment and Information Sciences, Yokohama National University for providing a research award through the International Environmental Leadership Program in Sustainable Living with Environmental Risk (SLER) and a research cooperation program for $\mathrm{PhD}$ students.

\section{Conflicts of interest}

All authors declared that there are no conflicts of interest.

\section{Ethical approval and consent to participate}

Not applicable.

\section{Consent for publication}

Not applicable.

\section{Copyright}

(c) The Author(s) 2022.

\section{REFERENCES}

1. Squadrone S, Prearo M, Brizio P, et al. Heavy metals distribution in muscle, liver, kidney and gill of European catfish (Silurus glanis) from Italian Rivers. Chemosphere 2013;90:358-65. DOI PubMed

2. Alkan N, Alkan A, Gedik K, Fisher A. Assessment of metal concentrations in commercially important fish species in Black Sea. Toxicol Ind Health 2016;32:447-56. DOI PubMed

3. Ali H, Khan E, Nasir MJ. Bioaccumulation of some potentially toxic heavy metals in freshwater fish of River Shah Alam, Khyber Pakhtunkhwa, Pakistan. PJZ 2020;52:603-8. DOI

4. Edwards J, Edyvane K, Boxall V, Hamann M, Soole K. Metal levels in Seston and Marine fish flesh near industrial and metropolitan centres in South Australia. Marine Pollution Bulletin 2001;42:389-96. DOI PubMed

5. Batzias AF, Siontorou CG. A new scheme for biomonitoring heavy metal concentrations in semi-natural wetlands. J Hazard Mater 2008;158:340-58. DOI PubMed

6. Sekhavatjou MS, Hosseini Alhashemi A, Rostami A. Comparison of trace element concentrations in ambient air of industrial and residential areas in Tehran city. Biol Trace Elem Res 2011;143:1413-23. DOI PubMed

7. Alibabić V, Vahcić N, Bajramović M. Bioaccumulation of metals in fish of Salmonidae family and the impact on fish meat quality. Environ Monit Assess 2007;131:349-64. DOI PubMed

8. Authman MM. Use of fish as bio-indicator of the effects of heavy metals pollution. J Aquac Res Development 2015;6:328-38. DOI

9. Farkas A, Salanki J, Specziar A, Varanka I. Metal pollution as health indicator of Lake Ecosystems. Int J Occup Med Environ Health 2001;14:63-170. PubMed

10. Naigaga I, Kaiser H, Muller W, et al. Fish as bioindicators in aquatic environmental pollution assessment: a case study in Lake Victoria wetlands, Uganda. Phys Chem Earth 2011;36:918-28. DOI

11. Zaqoot HA, Aish AM, Wafi HN. Baseline concentration of heavy metals in fish collected from Gaza fishing harbor in the Mediterranean Sea along Gaza Coast, Palestine. Turk J Fish Aquat Sci 2017;17:101-10. DOI

12. Afshan S, Ali S, Ameen US, Farid M, Bharwana SA, Hannan F, Ahmad R. Effect of different heavy metal pollution on fish. Res $J$ Chem Environ Sci 2014;2:35-40.

13. Bervoets L, Blust R, Verheyen R. Accumulation of metals in the tissues of three spined stickelback (Gasterosteus aculeatus) from natural fresh waters. Ecotoxicol Environ Saf 2001;48:117-27. DOI PubMed

14. Rajeshkumar S, Li X. Bioaccumulation of heavy metals in fish species from the Meiliang Bay, Taihu Lake, China. Toxicol Rep 2018;5:288-95. DOI PubMed PMC

15. Scharenberg W, Gramann P, Pfeiffer WH. Bioaccumulation of heavy metals and organochlorines in a lake ecosystem with special reference to bream (Abramis brama L.). Sci Total Environ 1994;155:187-97. DOI

16. Alam MG, Allinson G, Stagnitti F, Tanaka A, Westbrooke M. Arsenic contamination in Bangladesh groundwater: a major environmental and social disaster. Int J Environ Health Res 2002;12:235-53. DOI PubMed

17. Canbek M. Demir TA, Uyanoglu M, Bayramoglu G, Emiroglu O, Arslan N, Koyuncu O. Preliminary assessment of heavy metals in water and some Cyprinidae species from the Porsuk River, Turkey. J Appl Biol Sci 2007;1:91-5.

18. Shorna S, Quraishi SB, Hosen MM, et al. Ecological risk assessment of trace metals in sediment from the Old Brahmaputra River in 
Bangladesh. Chem Ecol 2021;37:809-26. DOI

19. Abalaka SE. Heavy metals bioaccumulation and histopathological changes in Auchenoglanis occidentalis fish from Tiga dam, Nigeria. J Environ Health Sci Eng 2015;13:67. DOI PubMed PMC

20. Håkanson L, Nilsson A, Andersson T. Mercury in fish in Swedish lakes. Environ Pollut 1988;49:145-62. DOI PubMed

21. Guven K, Ozbay C, Unlu E, Satar A. Acute lethal toxicity and accumulation of copper in Gammarus pulex (L.) (Amphipoda). Turk $J$ Boil 1999;23:513-21.

22. Adel M, Dadar M, Fakhri Y, Oliveri Conti G, Ferrante M. Heavy metal concentration in muscle of pike (Esox lucius Linnaeus, 1758) from Anzali international wetland, southwest of the Caspian Sea and their consumption risk assessment. Toxin Rev 2016;35:217-23. DOI

23. Roméo M, Siau Y, Sidoumou Z, Gnassia-barelli M. Heavy metal distribution in different fish species from the Mauritania coast. Sci Total Environ 1999;232:169-75. DOI PubMed

24. Sunlu U, Ozdemir E, Basaran A. The red mullet Mullus barbatus (Linnaeus 1758) as an indicator for heavy metal pollution in Izmir Bay (Turkey). 36th Ciesm Congress Proceedings; 2001 Sep 24-28; Monte Carlo. Monaco; 2001.

25. Varol M, Sünbül MR. Macroelements and toxic trace elements in muscle and liver of fish species from the largest three reservoirs in Turkey and human risk assessment based on the worst-case scenarios. Environ Res 2020;184:109298. DOI PubMed

26. Azevedo JS, Braga ES, Silva de Assis HC, Oliveira Ribeiro CA. Biochemical changes in the liver and gill of Cathorops spixii collected seasonally in two Brazilian estuaries under varying influences of anthropogenic activities. Ecotoxicol Environ Saf 2013;96:220-30. DOI PubMed

27. Iqbal J, Shah MH. Study of seasonal variations and health risk assessment of heavy metals in Cyprinus carpio from Rawal Lake, Pakistan. Environ Monit Assess 2014;186:2025-37. DOI PubMed

28. Shorna S, Shawkat S, Hossain A, et al. Accumulation of trace metals in indigenous fish species from the Old Brahmaputra River in Bangladesh and human health risk implications. Biol Trace Elem Res 2021;199:3478-88. DOI PubMed

29. Erdoğrul O, Erbilir F. Heavy metal and trace elements in various fish samples from Sir Dam Lake, Kahramanmaraş, Turkey. Environ Monit Assess 2007;130:373-9. DOI PubMed

30. Zhuang P, Li ZA, McBride MB, Zou B, Wang G. Health risk assessment for consumption of fish originating from ponds near Dabaoshan mine, South China. Environ Sci Pollut Res Int 2013;20:5844-54. DOI PubMed

31. Matouke MM, Abdullahi KL. Assessment of heavy metals contamination and human health risk in Clarias gariepinus [Burchell, 1822] collected from Jabi Lake, Abuja, Nigeria. Scientific African 2020;7:e00292. DOI

32. Hasan MK, Shahriar A, Hossain N, et al. Trace metals contamination in riverine captured fish and prawn of bangladesh and associated health risk. Expo Health 2021;13:237-51. DOI

33. Shohidullah Miah M. Climatic and anthropogenic factors changing spawning pattern and production zone of Hilsa fishery in the Bay of Bengal. Weather Clim Extrem 2015;7:109-15. DOI

34. Raknuzzaman M, Ahmed MK, Islam MS, et al. Trace metal contamination in commercial fish and crustaceans collected from coastal area of Bangladesh and health risk assessment. Environ Sci Pollut Res Int 2016;23:17298-310. DOI PubMed

35. . USEPA. Risk assessment guidance for superfund, vol. I: human health evaluation manual. EPA/540/1-89/002. Washington, DC: Office of Emergency and Remedial Response; 1989.

36. USEPA. Risk-based concentration table. 2010. Available from: http://www.epa.gov/reg3hwmd/risk/human/index.htm. [Last accessed on 5 Jan 2022].

37. ANZFA. Contaminants and natural toxicants (F2011C00542), Australian and New Zealand food standards code, standard 1.4.1. Available from: https://www.comlaw.gov.au/Details/F2011C00542 [Last accessed on 5 Jan 2022].

38. EC. Commission Regulation (EC) No 1881/2006 of the European parliament and the council of 19 December 2006 setting maximum levels for certain contaminants in foodstuffs. Official Journal of the European Communities L364/18 2006. Available from: http://eurlex.europa.eu/legal-content/EN/TXT/PDF/?uri=CELEX:32006R1881\&from=EN [Last accessed on 5 Jan 2022].

39. JECFA. Summary and Conclusions of the 61st Meeting of the Joint FAO/WHO Expert Committee on Food Additives 2003. Available from: https://apps.who.int/iris/handle/10665/42849 [Last accessed on 5 Jan 2022].

40. WHO. Heavy metals-environmental aspects. Environmental health criteria no. 85, World Health Organization, Geneva, Switzerland 1989. Available from: http://www.Who.Int/ipcs/publications/en. [Last accessed on 5 Jan 2022].

41. Al-yousuf M, El-shahawi M, Al-ghais S. Trace metals in liver, skin and muscle of Lethrinus lentjan fish species in relation to body length and sex. Sci Total Environ 2000;256:87-94. DOI PubMed

42. Usero J, Izquierdo C, Morillo J, Gracia I. Heavy metals in fish (Solea vulgaris, Anguilla anguilla and Liza aurata) from salt marshes on the southern Atlantic coast of Spain. Environ Int 2004;29:949-56. DOI PubMed

43. Wu SM, Jong KJ, Lee YJ. Relationships among metallothionein, cadmium accumulation, and cadmium tolerance in three species of fish. Bull Environ Contam Toxicol 2006;76:595-600. DOI PubMed

44. Ploetz DM, Fitts BE, Rice TM. Differential accumulation of heavy metals in muscle and liver of a marine fish, (king mackerel, Scomberomorus cavalla cuvier) from the Northern Gulf of Mexico, USA. Bull Environ Contam Toxicol 2007;78:134-7. DOI PubMed

45. Dural M, Göksu MZ, Ozak AA, Derici B. Bioaccumulation of some heavy metals in different tissues of Dicentrarchus labrax L, 1758, Sparus aurata L, 1758 and Mugil cephalus L, 1758 from the Camlik lagoon of the eastern coast of Mediterranean (Turkey). Environ Monit Assess 2006;118:65-74. DOI PubMed

46. Agah H, Leermakers M, Elskens M, Fatemi SM, Baeyens W. Accumulation of trace metals in the muscle and liver tissues of five fish species from the Persian Gulf. Environ Monit Assess 2009;157:499-514. DOI PubMed

47. de Conto Cinier C, Petit-ramel M, Faure R, Garin D, Bouvet Y. Kinetics of cadmium accumulation and elimination in carp Cyprinus 
carpio tissues. Comp Biochem Physiol 1999;122:345-52. DOI

48. Bustamante P, Bocher P, Chérel Y, Miramand P, Caurant F. Distribution of trace elements in the tissues of benthic and pelagic fish from the Kerguelen Islands. Sci Total Environ 2003;313:25-39. DOI PubMed

49. Sönmez AY, Yağanoğlu AM, Arslan G, Hisar O. Metals in two species of fish in Karasu River. Bull Environ Contam Toxicol 2012;89:1190-5. DOI PubMed

50. Sayg1 Y, Yiğit SA. Assessment of metal concentrations in two Cyprinid fish species (Leuciscus cephalus and Tinca tinca) captured from Yeniçağa Lake, Turkey. Bull Environ Contam Toxicol 2012;89:86-90. DOI PubMed

51. Delgado-Andrade C, Navarro M, López H, López MC. Determination of total arsenic levels by hydride generation atomic absorption spectrometry in foods from south-east Spain: estimation of daily dietary intake. Food Addit Contam 2003;20:923-32. DOI PubMed

52. Shah AQ, Kazi TG, Arain MB, et al. Accumulation of arsenic in different fresh water fish species - potential contribution to high arsenic intakes. Food Chem 2009;112:520-4. DOI

53. Han B, Jeng WL, Chen RY, Fang GT, Hung TC, Tseng RJ. Estimation of target hazard quotients and potential health risks for metals by consumption of seafood in Taiwan. Arch Environ Contam Toxicol 1998;35:711-20. DOI PubMed

54. Buchet JP, Lison D, Ruggeri M, Foa V, Elia G. Assessment of exposure to inorganic arsenic, a human carcinogen, due to the consumption of seafood. Arch Toxicol 1996;70:773-8. DOI PubMed

55. Fianko JR, Osae S, Adomako D, Adotey DK, Serfor-Armah Y. Assessment of heavy metal pollution of the Iture estuary in the central region of Ghana. Environ Monit Assess 2007;131:467-73. DOI PubMed

56. Y1lmaz F, Özdemir N, Demirak A, Tuna AL. Heavy metal levels in two fish species Leuciscus cephalus and Lepomis gibbosus. Food Chem 2007;100:830-5. DOI

57. Ahmed MK, Ahamed S, Rahman S, et al. Heavy metals concentration in water, sediments and their bioaccumulations in some freshwater fishes and mussel in Dhaleshwari River, Bangladesh. Terres Aquat Environ Toxicol 2009;3:33-41. DOI

58. Rahman MS, Molla AH, Saha N, Rahman A. Study on heavy metals levels and its risk assessment in some edible fishes from Bangshi River, Savar, Dhaka, Bangladesh. Food Chem 2012;134:1847-54. DOI PubMed

59. Matasin Z, Ivanusic M, Orescanin V, Nejedli S, Tlak Gajge I. Heavy metal concentrations in predator fish. J Anim Vet Adv 2011;10:1214-8. DOI

60. Ikem A, Egiebor NO. Assessment of trace elements in canned fishes (mackerel, tuna, salmon, sardines and herrings) marketed in Georgia and Alabama (United States of America). J Food Compos Anal 2005;18:771-87. DOI

61. Celik U. Determination of zinc and copper in fish samples collected from Northeast Atlantic by DPSAV. Food Chem 2004;87:343-7. DOI

62. Türkmen A, Türkmen M, Tepe Y, Akyurt İ. Heavy metals in three commercially valuable fish species from İskenderun Bay, Northern East Mediterranean Sea, Turkey. Food Chem 2005;91:167-72. DOI

63. Forti E, Salovaara S, Cetin Y, et al. In vitro evaluation of the toxicity induced by nickel soluble and particulate forms in human airway epithelial cells. Toxicol In Vitro 2011;25:454-61. DOI PubMed

64. Storelli MM, Barone G, Storelli A, Marcotrigiano GO. Trace metals in tissues of mugilids (Mugil auratus, Mugil capito, and Mugil labrosus) from the Mediterranean Sea. Bull Environ Contam Toxicol 2006;77:43-50. DOI PubMed

65. Rashed M. Monitoring of environmental heavy metals in fish from Nasser Lake. Environ Int 2001;27:27-33. DOI PubMed

66. García-Lestón J, Méndez J, Pásaro E, Laffon B. Genotoxic effects of lead: an updated review. Environ Int 2010;36:623-36. DOI PubMed

67. Farkas A, Salánki J, Specziár A. Age- and size-specific patterns of heavy metals in the organs of freshwater fish Abramis brama L. populating a low-contaminated site. Water Res 2003;37:959-64. DOI PubMed

68. Tuzen M. Toxic and essential trace elemental contents in fish species from the Black Sea, Turkey. Food Chem Toxicol 2009;47:178590. DOI PubMed 